„Etnografia Polska”, t. LXIII, 2019, z. 1-2 PL ISSN 0071-1861

DOI: $10.23858 /$ EP63.2019.001

AGNIESZKA HALEMBA

Instytut Archeologii i Etnologii, PAN

\title{
POSTRELIGIJNE I NIERELIGIJNE WYKORZYSTANIE BUDYNKÓW KOŚCIELNYCH NA PRZYGRANICZU ${ }^{1}$ POLSKO-NIEMIECKIM
}

Niemalże w każdej wsi położonej w północnej Brandenburgii i na Pomorzu Przednim (Vorpommern) jest kościół. Najczęściej to niewielki średniowieczny kamienny budynek, odnowiony i starannie utrzymany, stojący pośród regularnie koszonej trawy. W większości nabożeństwa odbywają się stosunkowo rzadko - czasem raz na miesiąc, czasem tylko jeden-dwa razy w roku. Jednak kościoły te nie są na ogół przekształcane w domy kultury, kawiarnie, galerie sztuki czy mieszkania. Co prawda czasem odbywają się w nich koncerty czy wystawy, jednak, w przeciwieństwie do budynków kościelnych w wielu innych częściach Europy, włączając w to zachodnie rejony Niemiec, na tym terenie nie zostają one trwale adaptowane do niereligijnego użytkowania (Frings i in. 2007; Meys, Gropp 2010; Willebrand 2013). Dzieje się tak, mimo iż tereny byłej NRD, a zwłaszcza jej północna i północno-wschodnia część, należą do najbardziej zsekularyzowanych regionów Europy, zarówno pod względem przynależności mieszkańców do organizacji religijnych, ich udziału w religijnych praktykach, jak i osobistych przekonań (Pollack 2002; Pollack, Pickel 2000; Wohlrab-Sahr 2011; Wohlrab-Sahr, Karsteina, Schmidt-Lux 2009). Niemal 90\% respondentów European Values Study $2017^{2}$ mieszkających w Brandenburgii i w Meklemburgii-Pomorzu Przednim na pytanie o rolę religii w ich życiu odpowiedziało, że jest ona nieważna lub zdecydowanie nieważna. Po drugiej stronie tego odcinka polsko-niemieckiej granicy, choć w porównaniu do Niemiec wschodnich rola religii w wielu jej aspektach zdaje się większa, to na tle innych regionów Polski sytuacja też jestdość jednoznaczna. W diecezji szczecińsko-kamieńskiej wskaźnik zarówno communicantes, jak i dominicantes jest najniższy w Polsce - odpowiednio 24,6\% i 11,2\% (Sadłoń 2019).

${ }^{1}$ Terminu „przygranicze” używam dla określenia znajdującego się w bezpośrednim sąsiedztwie granicy państwowej regionu, gdzie procesy graniczenia, tworzenia, wykorzystywania, przesuwania granicy mają znaczenie dla codziennych wyborów i praktyk mieszkańców (Green 2017; Halemba 2017).

${ }^{2}$ https://europeanvaluesstudy.eu/methodology-data-documentation/survey-2017/, dostęp 24.10.2019. 
W niniejszym artykule skupiam się na budynkach kościelnych w kontekście relacji polsko-niemieckich $\mathrm{w}$ tym regionie, postrzeganych poprzez pryzmat oddolnych inicjatyw nakierowanych na tworzenie wspólnej transgranicznej przestrzeni ${ }^{3}$. Nie twierdzę, że organizacje kościelne czy nawet ludzie wierzący biorą obecnie znaczący udział w budowaniu relacji polsko-niemieckich i że religia jest ważnym czynnikiem „tworzącym pogranicze” - tak, jak to tworzenie rozumieją lokalni aktywiści wspierający polsko-niemieckie inicjatywy i angażujący się w rozwój kontaktów na wielu poziomach (Halemba 2017). Przyjmuję natomiast, że odwołania do religii pojawiają się w tych procesach w sposób, który pozwoli nam na przyjrzenie się szerzej roli religii we współczesnej Europie i na dalsze prowadzenie refleksji nad procesami sekularyzacji i miejscem religii w zsekularyzowanym świecie. Moim celem jest przede wszystkim zwrócenie uwagi na to, że w regionie, który uważany jest za najmocniej zsekularyzowany w Europie, jeśli chodzi o niemiecką stronę granicy, elementy rozpoznawane lokalnie jako powiązane z religią pojawiają się w kontekście relacji polsko-niemieckich w nieoczekiwanie wyraźny sposób. Religia jest tu często punktem odniesienia, narzędziem, ale przede wszystkim zasobem, z którego korzystają miejscowi aktywiści, wcale niekoniecznie definiujący samych siebie jako aktorów religijnych.

Jednym z najważniejszych i najbardziej wpływowych elementów prac Talala Asada jest przeprowadzona przez niego analiza wzajemnego definiowania się świeckiego i religijnego, rozumianego, jako proces historyczny $(1993 ; 2003)$. W tym ujęciu nie jest możliwe zdefiniowanie religii przez wymienienie jej cech, ponieważ jest to kategoria historyczna, której rozumienie zależne jest każdorazowo od kontekstu społecznego, a przede wszystkim politycznego - religia jest pojęciem uwikłanym w relacje władzy. Z jednej strony możemy prześledzić rozwój tego pojęcia w chrześcijańskiej Europie; $z$ drugiej strony jest to kategoria zmieniająca swoją zawartość semantyczną w zależności od miejsca i czasu, a głównie w powiązaniu z relacją z jej nieodłącznym partnerem - świeckością, a przede wszystkim z władzą polityczną. Historia relacji między świeckim a religijnym jest historią ich wzajemnego definiowania się, co w gruncie rzeczy polega na opisywaniu i kategoryzowaniu pewnych rzeczy, ludzi i zdarzeń jako „religijne” czy „należące do sfery religijnej”, a innych jako „świeckie” czy „należące do sfery świeckiej”, oraz na walce o prawo do tegoż opisywania, osadzonego w działaniach, relacjach, organizacjach i instytucjach.

Chociaż niektórzy badacze zwracają uwagę, że rozdzielenie sfery świeckiej i religijnej nie jest jedynie europejską i chrześcijańską specjalnością (np. Wohlrab-Sahr, Burchhardt 2017), to kwestia ich wzajemnej relacji w Europie jest najczęściej dysku-

3 Artykuł ten powstał w wyniku badań prowadzonych w ramach grantu nr 2016-15 przyznanego przez Polsko-Niemiecką Fundację na Rzecz Nauki w latach 2016-2018, kontynuowanych w ramach grantu Narodowego Centrum Nauki nr 2019/33/B/HS3/02136 „Kościoły w świeckiej przestrzeni. Relacyjne podejście do odbudowy i użytkowania budynków kościelnych w północno-wschodnich Niemczech”. 
towana i najwyraźniej obecna. Sama literatura socjologiczna na temat miejsca religii w przestrzeni publicznej w Europie jest ogromna; to samo trzeba powiedzieć o badaniach dotyczących sekularyzmu i sekularyzacji. Wydaje się jednak, że mimo ogromu debat jednym z największych problemów dla socjologicznej i antropologicznej analizy jest względne ubóstwo i historyczne uwikłanie aparatu pojęciowego, niedostosowanego do prowadzenia badań i tworzenia opisów odpowiadających kierunkowi, jaki nadał badaniom nad religią/świeckością Asad. Jestem daleka od twierdzenia, że jest to jedyny kierunek w antropologicznych i socjologicznych badaniach nad religią, który warto zachować; jednakże uważam, że przynajmniej w kontekście europejskim jest on niezwykle pomocny w zrozumieniu współczesnych form obecności religii w różnych sferach życia; czy raczej powinnam powiedzieć, iż może byłby on pomocny, gdyby nie fakt, że badania nad religią, świeckością i sekularyzacją są blokowane, moim zdaniem, poprzez nieadekwatność używanych przez badaczy pojęć, które nie radzą sobie właśnie z historycznością kategorii.

W niniejszym artykule nie stawiam sobie ambitnego celu zaproponowania nowego aparatu pojęciowego, który mógłby pomóc nam w opisywaniu współczesnego splatania się świeckiego i religijnego, w terminach, które można by uznać za analityczne, a nie jedynie opisowe. Jednakże chciałabym, aby czytelnicy potraktowali ten artykuł jako krok właśnie w tym kierunku. Nie proponuję nowych pojęć, odchodzących słowotwórczo od tego, co już jest w badaniach nad miejscem religii w świeckiej przestrzeni dostępne; proponuję jednak kierunek, w którym takie badania mogłyby pójść metodologicznie, aby w końcowym rozrachunku do takich pojęć dojść. Punktem wyjścia i motywacją dla moich rozważań jest konstatacja, że doprowadzenie do logicznej konkluzji wpływowego twierdzenia Asada dotyczącego religii jako kategorii historycznej, pozostającej ze świeckim w ciągłym dialogu i negocjacji, oznacza przyjęcie, że kategorie świeckości i religii tworzą rzeczywistość, a nie ją reprezentują. Analizując zjawiska, w których badacze, uczestnicy zdarzeń bądź inni komentatorzy widzą aspekt religijny, mamy w gruncie rzeczy do czynienia z tworzeniem kategorii religii za każdym razem na nowo. Punktem wyjścia powinno być zatem przyjęcie perspektywy monistycznej, a wyjściowym pytaniem badawczym: dlaczego, po co i na jakich zasadach w danej sytuacji tworzona jest różnica między świeckim a religijnym?

W tym artykule będę posługiwać się pojęciami niereligijności i postreligijności, $\mathrm{w}$ formach przymiotnikowych: niereligijny i postreligijny. Podstawowe rozumienie terminu niereligijny wywodzę od definicji niereligii (nonreligion) zaproponowanej przez Johannesa Quacka (2014). Terminem tym określa on całą gamę stanowisk, które lokowane są, bądź same się lokują, poza polem religijnym, jednakże są z nim w istotny sposób powiązane. Religia jest dla takich zjawisk, grup czy działań ważnym punktem odniesienia - może być ona postrzegana jako przeciwnik, inspiracja czy, na przykład, dostarczycielka wrażeń estetycznych. Relacje z polem religijnym mogą mieć różny charakter i dotyczyć przekonań, ale także doświadczeń, estetyki, moralności czy aspektów prawnych. Zjawiskiem o charakterze niereligijnym jest na przykład działalność towarzystw humanistycznych (Engelke 2014; 2015), ale także fascynacja muzyką religijną ze strony osób uznających się za niewierzące, czy, jak 
w niniejszym artykule, wykorzystanie kościelnej architektury dla celów świeckich, z pełną świadomością religijnego charakteru tych budowli. Jak pisze Quack, ponieważ niereligia jest tak samo różnorodna jak religia, celem refleksji nad ich relacją jest zrozumienie, w jaki sposób w konkretnej sytuacji definiowana jest religia. W jakich momentach obiekty, wierzenia, postawy, rozumiane lokalnie jako religijne lub mające związek z religią zostają uznane za ważne dla pola niereligijnego? Najważniejszymi cechami tego podejścia są relacyjność i heurystyczny charakter koncepcji niereligii, która odnosi się do „różnych sposobów ustanawiania relacji między polem religijnym a pozycjami rozpatrywanymi jako wobec niego zewnętrzne” (Quack 2014, s. 448).

Samo pojęcie niereligii ma oczywiście długą historię, szczególnie w badaniach socjologicznych (patrz Wohlrab-Sahr, Kaden 2014) ${ }^{4}$. Najczęściej jest ono używane w odniesieniu do tak zwanych nones (ang.), czyli osób, które w rubrykach socjologicznych czy statystycznych kwestionariuszy badawczych przy pytaniu o wyznanie zaznaczały odpowiedź „nie dotyczy”. Większość badań wśród takich osób prowadzona była w paradygmacie intelektualistycznym, co oznacza, że badacze skupiali się przede wszystkim na badaniu przekonań (Lee 2012). Lois Lee proponuje zaś badania nad materialnością niereligii, zwracając uwagę na przykład na to, jak postawy niereligijne są materializowane czy ucieleśniane. Jednakże takie rozumienie niereligii jest nieco odmienne od tego, które pozwala na analizę zebranego przez mnie materiału; jest w moim odczuciu także odmienne od interpretacji Quacka. W niniejszym artykule proponuję przymiotnikowe i skalarne pojęcie „niereligijności”. Będę go używać w odniesieniu do relacji między osobą lub grupą osób określających się w danym miejscu i czasie jako nienależące do pola religijnego, a zjawiskiem, obiektem czy osobą postrzeganymi przez te pierwsze jako do tego pola w mniejszym lub większym stopniu przynależące. W tym ujęciu niereligijność nie jest trwałą cechą osoby, obiektu czy zjawiska, a relacją pomiędzy tym, co historycznie definiowane i rozpoznawane jako religijne, i tym, co samookreśla się jako świeckie.

Postreligijny zaś to określenie specyficznej formy niereligijnej relacyjności, zainspirowane pracami niemieckiego teologa Hansa Joachima Höhna (2006). Jego zdaniem w ostatnich dziesięcioleciach doszło do zmiany postrzegania religii w Europie. Nie jest już ona jego zdaniem traktowana jako metafizyczne spoiwo społeczne ani też jako rezerwuar odpowiedzi na pytania dotyczące sensu życia czy pochodzenia świata. Religia jest obecna głównie w wymiarze estetycznym i jako twórczyni nastrojów. Jest to, w mojej opinii, interesujący pogląd na pozycję chrześcijaństwa w Niemczech. Co ważne, w tym znaczeniu jako postreligijne mogą być określane działania osób określających się zarówno jako religijne, jak i niereligijne. Podsumowując, postreligijność odnosi się do takiego sposobu obecności elementów religijnych w danej relacji, które kładą nacisk przede wszystkim na potencjał historycznie definiowanej religii - a w moim przypadku religijnej materialności - do wzbudzania estetycznych przeżyć i budowania nastrojów.

${ }^{4}$ Interesujące badania $\mathrm{w}$ tym kierunku prowadzone są między innymi w ramach programu Understanding Unbelief, https://research.kent.ac.uk/understandingunbelief/, dostęp 05.12.2019. 


\section{RELIGIA NA PRZYGRANICZU}

Gdy rozpoczęłam w 2016 r. badania w ramach projektu Życie na granicy - transnarodowe praktyki mieszkańców polsko-niemieckiego pogranicza ${ }^{5}$, nie oczekiwałam, że kwestie religijne zatrzymają moją uwagę badawczą na dłużej. Nie było także moim celem poszukiwanie polsko-niemieckich inicjatyw o podłożu religijnym - nawet nie przypuszczałam, że wiele takich da się odnaleźć. Chciałam natomiast zorientować się, jaki mają stosunek do własnego życia religijnego i jak pamiętają czasy NRD członkowie wspólnot religijnych po niemieckiej stronie granicy. Można powiedzieć, że w praktyce ostatnie zdanie było moim początkowym pytaniem badawczym.

Badania rozpoczęłam od rozmów z członkami wspólnot religijnych i pastorami należącymi do dominującego w tym regionie Kościoła Ewangelickiego w Niemczech (EKD) ${ }^{6}$, których pytałam przede wszystkim o kształt życia religijnego w czasach NRD i zmiany, jakie zaszły po zjednoczeniu Niemiec. Zjednoczenie struktur politycznych, administracyjnych i gospodarczych RFN i NRD obejmowało także połączenie struktur kościelnych, jednak trudno tu mówić o wzajemnej adaptacji systemów dwóch niemieckich państw. W ocenie moich rozmówców hierarchia była od początku jasno ustalona i, co więcej, w początkowych latach akceptowana także przez większość wschodnioniemieckich obywateli - tak jak NRD zostało włączone w struktury RFN, tak kościoły działające w NRD zostały wchłonięte przez kościoły z Niemiec zachodnich, których praktyki organizacyjne zostały w dużej mierze przeniesione na wschód ${ }^{7}$.

Zjednoczenie Niemiec spowodowało znaczące zmiany w religijnym krajobrazie wschodniej części kraju. Choć nie nastąpiło oczekiwane przez niektórych badaczy odrodzenie religijne (Pollack, Pickel 2000), to jednak obecność wspólnot religijnych stała się zauważalna w nowy dla Niemiec wschodnich sposób. Obecnie, podobnie jak w Niemczech zachodnich, organizacje religijne prowadzą domy opieki, szkoły i przedszkola, organizują doradztwo psychologiczne i socjalne. Niektórzy autorzy zauważają również, że chociaż wspólnoty praktykujących i zaangażowanych religijnie osób są małe, to działają bardzo aktywnie (Hafner, Völkening, Becci 2018; Peperkamp, Rajtar 2010). Jednym z obszarów działań wspólnot religijnych jest utrzymanie i odbudowa budynków kościelnych.

Relacje polsko-niemieckie pojawiły się w moich rozmowach z członkami wspólnot religijnych i obserwacjach, które prowadziłam, właśnie w kontekście użytkowania budynków kościelnych. Miał na to wpływ fakt, że po wejściu Polski do Unii

\footnotetext{
${ }^{5}$ Projekt nr 2016-15 finansowany przez Polsko-Niemiecką Fundację na Rzecz Nauki w latach 20162018. Badania zostały przeprowadzone przez pracowników i studentów Uniwersytetu Warszawskiego i Uniwersytetu w Hamburgu. W trakcie trwania projektu tytuł został zmieniony na Życie na granicy - transgraniczne praktyki mieszkańców polsko-niemieckiego przygranicza.

6 EKD jest unią 20 kościołów lokalnych: augsburskich, unijnych i reformowanych.

${ }^{7}$ W ostatnich latach rozpoczęły się w Niemczech publiczne debaty dotyczące tego, w jaki sposób zostało przeprowadzone zjednoczenie Niemiec i wynikające z niego reformy (np. Engler, Hensel 2018; Köpping 2018).
} 
Europejskiej, a szczególnie do sfery Schengen, po niemieckiej stronie granicy zaczęło osiedlać się wiele polskich rodzin, które przyciągały przede wszystkim niższe niż w Szczecinie ceny nieruchomości, ale także chęć życia z dala od zgiełku miasta czy możliwość edukacji dzieci w dwóch językach (Balogh 2013; Rutkowska 2019). Jednym z pobocznych aspektów tego zjawiska jest zwiększona obecność katolików na tym terenie. Choć nie można powiedzieć, żeby życie religijne było priorytetem dla Polaków sprowadzających się na niemiecką stronę granicy, to jednak wielu z nich jest przynajmniej kulturowymi katolikami - uważają, że dziecko powinno zostać ochrzczone, przystąpić do pierwszej komunii świętej, a nowa rodzina zostać zatwierdzona ślubem kościelnym. Są wśród nich także zarówno otwarci krytycy Kościoła katolickiego, jak i osoby głęboko wierzące. Co jednak ważne, religia jest dla wielu $\mathrm{z}$ nich istotnym punktem odniesienia - czy to poprzez udział w praktykach religijnych, czy przez jasno wyrażaną krytykę Kościoła katolickiego. Moim zdaniem pojawienie się osób, które mają jasny stosunek do religii i Kościoła, czy to jako osoby praktykujące, zadeklarowane, czy nawet jako krytycy, sprawiło, że religia stała się $\mathrm{w}$ tym regionie, zamieszkałym przez już nie tyle protestanckich, co areligijnych Niemców, bardziej widoczna.

Jednym z niewielu badaczy zajmujących się kwestią architektury religijnej na polsko-niemieckim przygraniczu i jej roli w polsko-niemieckich relacjach jest Aleksander Tölle $(2013 ;$ 2016). Zaznacza on, że „w regionie naznaczonym przez trudną sytuację społeczno-ekonomiczną, takim jak obszar wzdłuż granicy polsko-niemieckiej, można oczekiwać pozytywnego impulsu miejsc, które zamiast handlu i konsumpcji symbolizują tożsamość, refleksję, wartości chrześcijańskie i tolerancję" (Tölle 2013, s. 123). W ten sposób autor ten wyznaczył swoje oczekiwania wobec budynków kościelnych - mają one pozytywnie wpływać na polsko-niemieckie relacje. Konkretne przykłady, które Tölle analizuje: to renowacja kościoła w Chojnie przy udziale polsko-niemieckiej fundacji; odbudowa fary w Gubinie jako miejsca spotkań; oraz odbudowa Kościoła Pokoju we Frankfurcie nad Odrą jako centrum ekumenicznego. Autor skupia się na pokazaniu, w jaki sposób dane miejsca wzmacniają polsko-niemiecki dialog czy przyczyniają się do przełamywania „zmowy milczenia” na temat charakteru polsko-niemieckich relacji w przeszłości. Religia w jego interpretacji to element pozytywny, działający niezależnie od różnic denominacyjnych. Jeśli przyjąć taką interpretację, to dotychczasowa literatura antropologiczna analizująca wykorzystanie jednego miejsca kultu przez przedstawicieli rożnych religii bądź denominacji i wskazująca, że raczej wzmacnia ono niż niweluje poczucie różnicy, nie miałaby tu zastosowania (Hayden 2002; Lubańska 2017). Co więcej, samo nawiązanie relacji postrzegane jest przez tego autora jako jednoznacznie pozytywne, choć takie rozumienie relacji jest uważane we współczesnej antropologii za uproszczenie (Strathern 2018).

W niniejszym artykule proponuję podejście, które nie traktuje religii jako czynnika a priori pozytywnie wpływającego na relacje. Zamiast tego zwracam uwagę na istnienie wielu poziomów skomplikowanego dialogu prowadzonego na poziomie lokalnym. Architektura religijna w Europie jest elementem odbieranym przez wiele 
osób, także tych deklarujących się jako niereligijne, jako ważny i pożądany element przestrzeni publicznej (Davie 2006). Christopher Kiley, pisząc o adaptacji budynków kościelnych do celów niereligijnych w USA, zwracał uwagę na ich miejsce w krajobrazie, widząc w nich swego rodzaju kotwice, których potężna obecność wizualna może zostać - jego zdaniem - uznana za „dobro publiczne” (2004, s. 13). Poniżej przedstawiam przykłady niereligijnego, religijnego i postreligijnego wykorzystania budynków kościelnych w kontekście relacji polsko-niemieckich.

\section{NIEMIECKO-POLSKI KOŚCIÓŁ PAMIĘCI W ROSOW}

Rosow jest niewielką miejscowością (ok. 150 mieszkańców) położoną zaledwie kilkaset metrów od polskiej granicy i piętnaście kilometrów na południe od Szczecina. W 2018 r. wieś obchodziła swoje 775-lecie (Lau i in. 2018, s. 11). Średniowieczny kamienny kościół z nietypową ażurową wieżą zdecydowanie dominuje w krajobrazie wsi. Osobie z zewnątrz może się wydawać, że mamy tu do czynienia nie tyle z kościołem pośrodku wsi, co z kilkoma domami ustawionymi przy ulicach zbiegających się ku kościołowi. Przed kościołem stoi niewielki obelisk $\mathrm{z}$ większym napisem po niemiecku i mniejszym po polsku: „ku pamięci milionów polskich i niemieckich uchodźców II wojny światowej”. Od 2007 r. kościół ten nosi nazwę „Niemiecko-polskiego Pomnika Pamięci o Ucieczce, Wygnaniu i Nowym Początku" (Deutsch-Polnische Gedenkstätte für Flucht, Vertreibung und Neuanfang) i jest zarządzany przez świeckie stowarzyszenie, które zostało powołane w celu odbudowy kościoła na początku XXI wieku. Jak można przeczytać chociażby na stronie niemieckiej Wikipedii, „budynek ten jest pomnikiem, ale wciąż oferuje możliwość odprawiania nabożeństw miejscowej wspólnocie religijnej w Rosow"'. Status tej budowli jako kościoła i kwestia odprawiania w nim nabożeństw w praktyce jednak wcale nie są oczywiste. Jednym z wielu pytań, które zadawali sobie moi rozmówcy, było to, czy jest to nadal kościół?

Budowla ta została częściowo zniszczona podczas ostatnich dni II wojny światowej. Mimo to do początku lat 70. służyła miejscowej protestanckiej wspólnocie religijnej jako miejsce modlitw. Dopiero wówczas została zamknięta, ze względu na stan techniczny ${ }^{10}$. Wierni przenieśli się do plebanii. W połowie lat 80 ., mimo zmniejszającej się liczby parafian, ówczesny pastor podejmował starania w kierunku odbudowy kościoła, przy wsparciu zaprzyjaźnionej parafii z RFN. Jednak na dobre działania na rzecz odbudowy kościoła ruszyły dopiero po 1990 r. Na początku lat 90. do Rosow przyjechała 89-letnia Ilse Scheller, córka pastora Friedricha Marquardta,

${ }^{8}$ Zdecydowałam się na pozostawienie niezmienionych nazw miejscowości, a jednocześnie na niepodawanie ani nazwisk moich rozmówców, ani żadnych danych, które pozwoliłyby na ich łatwą identyfikację.

${ }^{9}$ https://de.wikipedia.org/wiki/Ged\%C3\%A4chtniskirche_Rosow, dostęp 05.12.2019.

${ }_{10}$ Także w NRD remontowano i budowano kościoły, częściowo na koszt zaprzyjaźnionych wspólnot religijnych z Niemiec Zachodnich (patrz Dohmann 1964). Jednak na remont kościoła w Rosow wtedy się nie zdecydowano. 
który służył w tej miejscowości w latach 1905-1932. Jak powiedział mi jeden z jej wnuków, to jej, wyrażona podczas tej wizyty, prośba o odbudowę kościoła zmotywowała zarówno krewnych, jak i innych byłych i obecnych mieszkańców Rosow do działania. Znalazła się grupa osób, która podjęła to wyzwanie, i rozpoczęło się zbieranie funduszy i organizacja całego przedsięwzięcia.

Należy zaznaczyć, że w tamtym czasie na terenie byłego NRD odbudowywano wiele kościołów. Jednakże kościół w Rosow, zapewne ze względu na niewielką liczbę wiernych, jak też stan techniczny, nie został przyjęty do żadnego z programów odbudowy kościołów prowadzonych przez EKD ani przez żadną związaną z nim fundację. Dopiero w 2002 r. powstało świeckie stowarzyszenie odbudowy kościoła w Rosow (Förderkreis Gedächtniskirche Rosow), które podjęło negocjacje z władzami kościelnymi na temat jego renowacji. Zdecydowano, że budynek (a raczej jeszcze wtedy jego ruina) zostanie na 25 lat wydzierżawiony stowarzyszeniu, które zobowiąże się do jego odbudowy, prowadzenia w nim działalności kulturalnej, i, co ważne, udostępniania go w razie potrzeby do działalności religijnej. Status budynku stał się w ten sposób dość skomplikowany: miał się on znajdować poza jurysdykcją władz kościelnych przynajmniej przez ćwierć wieku, a o jego wykorzystaniu miało decydować świeckie stowarzyszenie; jednocześnie jednak stowarzyszenie to miało obowiązek tak zarządzać budynkiem i taki kształt nadać jego wnętrzu, aby bez problemu można było tam odprawiać nabożeństwa.

Co więcej, remont został sfinansowany w ramach programów pomocy finansowej Unii Europejskiej jako polsko-niemieckie miejsce pamięci, co nakazuje stowarzyszeniu prowadzenie działalności upamiętniającej polskie i niemieckie doświadczenia lat powojennych związane z ucieczką, wypędzeniem i nowym początkiem. Pomysł utworzenia w budynku kościoła takiego miejsca powstał przez dostosowanie celu stowarzyszenia, dla którego najważniejsza była renowacja budynku, do istniejących propozycji grantowych Euroregionu Pomerania. Aby przekonać potencjalnych sponsorów, musiał zostać rozwinięty tak zwany Nutzungskonzept - projekt użytkowania - który by wychodził poza kwestie religijne. Ze względu na historię Rosow ${ }^{11}$ postanowiono, że stanie się on „Pomnikiem pamięci o ucieczce, wypędzeniu i nowym początku". Jednakże, gdy stowarzyszenie wystąpiło do Euroregionu Pomerania o wsparcie, finansowanie zostało początkowo przyznane, lecz następnie wstrzymane, ze względu na protest strony polskiej. Trzeba pamiętać, że działo się to w pierwszych latach XXI wieku, w czasie, gdy w polskich mediach głośno było o działalności Związku Wypędzonych w Niemczech i planowanej przez to stowarzyszenie budowie Centrum Przeciwko Wypędzeniem (Röger 2016; Zaborski 2007). Moi rozmówcy

${ }^{11}$ Rosow było przed II wojną światową dość zamożną wsią, gdzie zamieszkiwali posiadacze większych gospodarstw. Większość z nich opuściła wieś w ostatnich tygodniach wojny. Opuszczone domy zostały zasiedlone przez uciekinierów z ziem zajętych przez Armię Czerwoną, a następnie przyznanych Polsce. Po 1949 r. władze NRD osiedlały w Rosow osoby z różnych regionów kraju, które otrzymywały nakaz pracy w miejscowym gospodarstwie rolnym. Z przedwojennych mieszkańców w Rosow, jak mi mówiono, pozostały dwie rodziny, w tym rodzina przewodniczącego stowarzyszenia zajmującego się odbudową kościoła. 
zostali poinformowani, że kwestia upamiętnienia wypędzeń musi zostać przedstawiona w kontekście zarówno polskim, jak i niemieckim. Była to dla stowarzyszenia idea nowa, lecz w pełni akceptowalna - położenie Rosow tuż przy granicy polsko-niemieckiej sprawiało, że włączenie doświadczenia polskiego wydawało się w pełni naturalne. Właśnie w ten sposób powstał obecny kościól „Polsko-niemiecki Pomnik Pamięci, Ucieczki Wypędzenia i Nowego Początku” w Rosow.

W 2007 r. kościół został otwarty. Co ciekawe, projekt odbudowy „autentycznego” kościoła został w tym wypadku przełamany - wieży kościoła nadano formę ażurowej stalowej konstrukcji. Z jednej strony był to wybór ekonomiczny, ponieważ odbudowa, a właściwie budowa na nowo średniowiecznej wieży przekraczała możliwości stowarzyszenia. Z drugiej jednak strony ażurowa konstrukcja wieży miała wskazywać na to, że nie jest to po prostu rekonstrukcja dawnego kościoła i przeszłości, a raczej miejsce pamięci mające skłaniać do refleksji. Miały temu służyć też zebrane w kościele materiały, głównie transkrypcje rozmów z osobami, które w wyniku II wojny światowej podlegały przymusowej migracji.

Współpraca polsko-niemiecka przejawia się na wiele sposobów. Kilka razy w roku organizowane są koncerty z udziałem polskich muzyków, a mniej więcej raz w roku odbywa się nabożeństwo ekumeniczne, w którym biorą udział zaprzyjaźnieni z członkami stowarzyszenia zarówno pastorzy, jak i księża katoliccy. Przez pierwsze lata byli to proboszczowie z Żabnicy, wsi po polskiej stronie granicy, a w ostatnich latach w przygotowaniu nabożeństw bierze udział ksiądz, profesor teologii z Uniwersytetu Szczecińskiego, który kilka lat temu zamieszkał w budynku dawnej restauracji w Rosow, znajdującym się naprzeciw odbudowanego kościoła. Jednakże ta aktywność religijna napotyka pewne problemy właśnie ze względu na niejasny status budynku. Oficjalnie nie ma on przydzielonego pastora (nie jest to tzw. Predigtstelle), a należy do świeckiego stowarzyszenia. Za każdym razem, gdy stowarzyszenie chce poprosić jakiegoś pastora o odprawienie nabożeństwa, musi wystąpić o zgodę dziekana odpowiedzialnego za ten teren ${ }^{12}$. Jest to swojego rodzaju paradoks - prowadzenie działalności religijnej jest przecież wpisane do umowy pomiędzy stowarzyszeniem a EKD. Jeśli jednak stowarzyszenie chce odprawić w kościele nabożeństwo, musi prosić o pozwolenie. Natomiast gdy chce zorganizować koncert lub wystawę, takie pozwolenie nie jest potrzebne.

Ksiądz mieszkający w Rosow przyjechał tu jako jeden z Polaków, którzy od ponad 10 lat osiedlają się na terenach po niemieckiej stronie granicy. Przez lata ci z Polaków, którzy chcieli brać udział w katolickich nabożeństwach, jeździli do pobliskich polskich parafii lub do swoich dawnych parafii w Szczecinie i okolicach. Ksiądz z Rosow uznał jednak, że jego obowiązkiem jest zapewnienie opieki duszpasterskiej na miejscu, nawet jeśli w okrojonym zakresie. W dawnej sali restauracyjnej przygotował kaplicę, gdzie obecnie co niedzielę odprawia msze święte. Działa także na innych polach: organizuje półkolonie letnie dla polskich i niemieckich dzieci, koncerty, wyjazdy pielgrzymkowe, a także takie nabożeństwa jak Droga Krzyżowa. Wokół domu planuje założenie ogrodu

${ }^{12}$ Dziekan przekazał po pewnym czasie swoje plenipotencje $\mathrm{w}$ tym zakresie pastorowi z pobliskiego Gartz. 
biblijnego, będącego miejscem zadumy i refleksji. Stopniowo stał się też naturalnym partnerem dla polsko-niemieckich inicjatyw organizowanych wokół kościoła w Rosow. Bierze udział we wszelkich lokalnych polsko-niemieckich wydarzeniach w kościele i poza nim. Jego obecność i aktywność wpływają na dynamikę działań wokół „Polsko-niemieckiego Kościoła Pamięci w Rosow". Jak mi powiedzieli zarówno przewodniczący stowarzyszenia, jak i ksiądz, dotychczas odbyły się jedynie bardzo wstępne rozmowy, czy raczej sugestie, związane z ewentualnym wykorzystaniem budynku przez katolików. Ksiądz może w każdej chwili wziąć klucz do kościoła i zorganizować tam spotkanie, także modlitewne, czy pokazać kościół odwiedzającym, szczególnie jeśli to wydarzenie będzie miało polsko-niemiecki charakter. Jednakże cotygodniowe msze święte odprawiane są nadal w budynku dawnej restauracji.

Czy kościół w Rosow jest nadal kościołem? Czy była restauracja jest miejscem religijnym? Co i gdzie powinno się odbywać? Czy użytkowanie dla celów religijnych, zapisane w Nutzungskonzept, obejmuje także wyznania nieprotestanckie? A jak ze świeckimi pogrzebami czy innymi uroczystościami? Są to pytania, które nurtują nie tylko mnie, ale także osoby zaangażowane w odbudowę kościoła. W tym kontekście niezmiernie ciekawa była rozmowa przeprowadzona przeze mnie z dziekanem (Propst) odpowiedzialnym za ten region. W jego interpretacji budynek ten nie jest w chwili obecnej kościołem, ponieważ został przekazany w użytkowanie świeckiemu stowarzyszeniu. Co będzie, gdy termin dzierżawy upłynie, pokaże czas. Za pozwoleniem pastora $\mathrm{z}$ Gartz lub dziekana można tam odprawiać nabożeństwa, jednak głównie prowadzona powinna być tam działalność kulturalna - czyli może być on wykorzystywany niereligijnie. Jednakże jego zdaniem budynek ten nie powinien być wykorzystywany postreligijnie - nie powinien służyć, nawiązując do słów Höhna (2006), do wytwarzania nastroju czy atmosfery. Dziekan jest na przykład przeciwnikiem organizowania w tym budynku świeckich ślubów i pogrzebów. W jego opinii indywidualna rezygnacja $\mathrm{z}$ religii powinna pociągać za sobą także rezygnację z religijnej materialności, takiej na przykład jak religijna architektura. Zwrócił uwagę na to, że w tym regionie, jak się wyraził „ludzie nie tylko zapomnieli o wierze, ale także zapomnieli, iż zapomnieli", ale jednak młode pary biorące świecki ślub jadą z urzędu pod miejscowy kościól, aby się przed nim sfotografować. Dziekan uważał, że takie zachowanie jest nieuprawnionym zawłaszczeniem sfery religijnej. Mieszkańcy Rosow uznali natomiast za nieuprawnione użycie kościoła zaproponowane w 2017 roku przez nowo przybyłą $\mathrm{w}$ te okolice kobietę, która chciała w nim prowadzić w miesiącach letnich kawiarnię. Zaprotestowali przeciw tej inicjatywie także ci mieszkańcy Rosow, którzy do żadnej wspólnoty religijnej nie należą.

Proces odbudowy kościoła w Rosow problematyzuje relacje między świeckim a religijnym użytkowaniem - pojęcia postreligijności i niereligijności mogą nam pomóc w ich zrozumieniu. Jednakże muszą być traktowane relacyjnie i skalarnie. Granice tworzone między świeckim a religijnym są nie tyle zmienne, co płynne, porowate czy nawet przede wszystkim stopniowalne. W poszczególnych sytuacjach stawką nie jest to, czy dane wydarzenie, postawa, działanie należą do porządku świeckiego czy religijnego, ale jak bardzo do któregoś z nich należą. 


\section{WIGILIA NAD ODRĄ}

W przeciwieństwie do sprawy kościoła w Rosow nikt nie ma wątpliwości, że średniowieczny budynek w leżącej nad samą Odrą miejscowości Mescherin jest kościołem. Odbywają się tam raz lub dwa razy w miesiącu nabożeństwa, na ogół przy udziale zaledwie kilku wiernych. Odprawiane są przez pastora rezydującego w Gartz, oddalonym od Mescherin o 10 kilometrów. Kościół ten, tak jak i inne kościoły w tym regionie, jest także regularnie wykorzystywany jako sala koncertowa. Jednakże koncerty organizowane są tam nieco częściej - niewielki Mescherin już przed I wojną światową był miejscowością turystyczną, a szczególnie miejscem krótkich wycieczek z pobliskiego Szczecina. W czasach NRD ten wypoczynkowy charakter miejscowości się zachował, a od początku lat 90. malowniczo położona miejscowość przyciąga zarówno odwiedzających, jak i osoby z większych miast chcące zamieszkać na stałe w pięknym otoczeniu. Koncerty w Mescherin cieszą się zatem sporą popularnością.

Od kilku lat jednym $\mathrm{z}$ najbardziej spektakularnych wydarzeń w Mescherin jest polsko-niemiecka Wigilia nad Odrą, organizowana od 2014 r. przy współpracy różnych lokalnych organizacji: gminy Mescherin; stowarzyszenia Pokolenia Pokoleniom z polskiego Gryfina, znajdującego się dokładnie po drugiej stronie Odry oraz organizacji pozarządowej RAA Perspektywa rezydującej w Löcknitz. Spotkania wigilijne odbywają się według programu, który zmienia się co roku, jednak w głównym zarysie pozostaje taki sam.

Uroczystość rozpoczyna się w kościele w Mescherin - według organizatorów zbiera się tam około 200 osób, w tym wielu gości z Gryfina. Gdy brałam udział w Wigilii nad Odrą w 2016 r., przed wejściem do kościoła płonęły potężne pochodnie - trzeba było między nimi przejść, aby dostać się do środka. Spotkanie prowadzili Marta Szuster, dwujęzyczna mieszkanka Mescherin i miejscowa radna, oraz Marek Brzeziński, radny z Gryfina, twórca i działacz społeczny. Wszystko było tłumaczone na polski i niemiecki. Głównym tematem spotkań wigilijnych jest pamięć i historia mówiona - zwykle program zorganizowany jest wokół wspomnień konkretnych osób związanych od wielu lat $\mathrm{z}$ regionem: są to raczej starsze osoby pamiętające czasy wojenne lub tuż powojenne albo potomkowie dawnych mieszkańców regionu. W 2016 r. główną postacią był Hans Paasche, niemiecki pisarz i pacyfista, zamordowany prawdopodobnie przez prawicowo nastawionych żołnierzy już w $1920 \mathrm{r}^{13}$, oraz dwie mieszkanki regionu: Helena Woźniewicz oraz Renate Knop. Wigiliom towarzyszy muzyka: kolędy i protestanckie pieśni bożonarodzeniowe, a także muzyka klasyczna czy inne nastrojowe utwory.

Dla mojej interpretacji ważne jest to, że organizatorzy definiują to spotkanie jako należące do sfery świeckiej, a jednocześnie wykorzystują wiele elementów, które mają źródła w religii chrześcijańskiej. To ostatnie służy właśnie temu, na co zwrócił uwagę Höhn, pisząc o postreligii, a co ja nazywam tworzeniem postreligijnych relacji między religijnym a świeckim. W rozmowie z jednym z polskich organizatorów Wigilii nad

\footnotetext{
${ }^{13} \mathrm{https} / / /$ hanspaaschepl.wordpress.com/, dostęp 11.12.2019.
} 
Odrą spytałam, czy przewidziane jest jakieś krótkie słowo księdza lub pastora, czy moment ekumenicznej modlitwy - w końcu zaproszenia w języku polskim wskazywały na ekumeniczny kościół w Mescherin jako miejsce spotkania ${ }^{14}$. W odpowiedzi usłyszałam, że nie będzie tam księdza ani pastora ${ }^{15}$, nie będzie żadnej modlitwy, a jeśli ktoś by miał ją zamiar wprowadzić, to mój rozmówca zrezygnowałby z udziału, ze względu na swój negatywny stosunek do kościoła jako organizacji. Podkreślił, że nie jest to wydarzenie religijne, a spotkanie sąsiadów służące wzajemnemu poznaniu się.

Dlaczego zatem całe to spotkanie nie jest organizowane w gminnym domu spotkań, gdzie po koncercie wszyscy udają się na poczęstunek i rozmowę przy kawie? Oczywiście można powiedzieć, że jest to kwestia wielkości sali - kościół oferuje po prostu więcej miejsca. Jednak sądzę, że chodzi tu jeszcze o to, co można nazwać wymiarem postreligijnym. Elementy mające korzenie w kulcie religijnym (opłatek, kolędy, architektura kościelna) są wykorzystywane dla wywołania atmosfery powagi i skupienia wśród uczestników. Piękno architektury, światła i muzyki tworzy nastrój zadumy, ale też istotności podejmowanych kwestii. Nade wszystko wspierają one czy nawet legitymizują dyskurs wspólnotowości przygranicznej i dobrosąsiedztwa podkreślany przez organizatorów.

Birgit Meyer i Mattijs van de Port (2018) zasugerowali, że w badaniach antropologicznych konieczne jest pokazanie nie tylko tego, że dana narracja, miejsce pamięci czy tożsamość są konstruowane, ale także jak właściwie ta konstrukcja powstaje. Jak to się dzieje, że konstruowana rzeczywistość staje się „naprawdę realna” dla zaangażowanych ludzi? Autorzy ci piszą o „estetyce perswazji” koniecznej, aby ludzie postrzegali pewne formy, rzeczy lub praktyki jako „autentyczne”. Moim zdaniem religijna architektura, muzyka czy rytuały są wykorzystywane we współczesnej Europie właśnie do tworzenia „naprawdę realnej” rzeczywistości, innymi słowy do budzenia emocji i wrażeń także na poziomie przedrefleksyjnym. Co ciekawe, dzieje się tak także $\mathrm{w}$ regionach, gdzie religia, wydawałoby się, straciła na znaczeniu.

\section{CHRZEŚCIJAŃSTWO ZJEDNOCZONE, CZYLI WIEŻE ZAMIAST MINARETÓW}

Ostatni przykład dotyczy wpływu sfery świeckiej, w tym przypadku politycznej, na sferę religijną. Przedstawię krótki wycinek historii użytkowania jeszcze jednego budynku kościelnego, usytuowanego w trzytysięcznym Löcknitz. Jak widać

${ }^{14}$ Tak było podane na zaproszeniu w 2016 r. w języku polskim. Jako miejsce Wigilii nad Odrą wskazano ekumeniczny kościół w Mescherin (patrz np. https://www.perspektywa.de/pl/termin/wigilia-nad-odra). W języku niemieckim wpisany był po prostu kościół wiejski w Mescherin (https://www. perspektywa.de/de/termin/weihnachten-an-der-oder). Co ciekawe, gdy zwróciłam uwagę na tę różnicę w obecności niemieckich organizatorów, byli oni zdziwieni i w już w następnym roku na zaproszeniach pojawił się w obu językach jako miejsce Wigilii nad Odrą ewangelicki kościół w Mescherin (https://www. facebook.com/pokolenia.gryfino/photos/gm.1975515286056558/2009188465988811/?type=3\&theater).

15 Oczywiście mogą tam być jako prywatne osoby. 
w dwóch powyżej opisanych przypadkach, katolicy, protestanci, a także osoby niereligijne mogą wspólnie użytkować budynki kościelne, a negocjacje i dyskusje związane z ich wykorzystaniem pozwalają na analizę znaczenia elementów wywodzących się z historycznie ukształtowanej praktyki religijnej we współczesnym świecie, także w niereligijnych kontekstach. Zarówno w Mescherin, jak i w Rosow budynki kościelne są wykorzystywane w celach niereligijnych. Trzeci przykład to sytuacja, gdy specyficzne regulacje dotyczące religijnego użytkowania budynków podejmowane są ze względu na sytuację polityczną.

Budynek kościoła w Löcknitz jest stosunkowo nowy - zbudowany został w połowie XIX wieku. Jest to duży kościół salowy z żółtej cegły, działający nieprzerwanie w czasach NRD. Wszelkie uszkodzenia wojenne zostały naprawione zaraz po II wojnie światowej, a w czasach socjalistycznych przeprowadzono wiele prac remontowych, włączając w to instalację nowych organów, dzwonów czy chrzcielnicy. Nieprzerwanie też w kościele tym rezydowali pastor lub pastorka. Jednakże liczba aktywnych wiernych z czasem się zmniejszała i obecnie w protestanckich nabożeństwach w trzytysięcznym Löcknitz udział bierze zaledwie kilka, najwyżej kilkanaście osób.

Löcknitz jest jednocześnie jednym z głównych punktów osiedlania się Polaków w tym regionie. Miejscowość ta ma dobre kolejowe, drogowe i autobusowe połączenie ze Szczecinem, znajduje się w nim działające już ponad 20 lat polsko-niemieckie gimnazjum, są sklepy i restauracje. Przez kilka lat Polacy z Löcknitz jeździli na katolickie nabożeństwa do najbliższego kościoła w Polsce, znajdującego się w położonym sześć kilometrów od granicy Mierzynie. W Mierzynie, tak jak w większości miejscowości w regionie, także po polskiej stronie granicy, kościół parafialny to mały, średniowieczny, kamienny budynek, który nie może pomieścić wszystkich chętnych. Biorąc pod uwagę także to, że Szczecin od czasu wejścia Polski do strefy Schengen zaczął rozrastać się w kierunku zachodnim, w Mierzynie zdecydowano, że w parafii potrzebny jest nowy, nowoczesny i przede wszystkim duży kościól, którego budowa obecnie trwa.

Można powiedzieć, że katolickie biskupstwo w Berlinie, odpowiedzialne za teren po niemieckiej stronie granicy, przez pierwsze lata po wejściu Polski do Unii Europejskiej i do strefy Schengen nie doceniało znaczenia i tempa wzrostu liczebności katolików na tym terenie, gdzie do niedawna katolickie msze odbywały się jedynie w największych miejscowościach i w języku niemieckim. Dopiero od października 2016 roku w Löcknitz odbywają się katolickie msze w języku polskim. Co ciekawe, odprawiane są one w miejscowym kościele, należącym do wspólnoty protestanckiej. W Löcknitz jest pastor, a od 2016 roku nawet para pastorska, odpowiedzialna za obsługę kilku wspólnot religijnych w okolicy i odprawianie nabożeństw w ich kościołach. Jednak od końca 2016 roku w samym Löcknitz wspólnota protestancka organizuje własne nabożeństwa nie w głównym kościele, a w salce parafialnej. W głównym kościele spotykają się katolicy, na mszach w języku polskim odprawianych przez księdza z Passewalk, który w tej ostatniej miejscowości służy $\mathrm{w}$ języku niemieckim. Według pastora i pastorki $\mathrm{z}$ jednej strony jest to wygodne 
dla obu wspólnot religijnych - katolicy mają gdzie odprawiać msze, a protestanci zyskali wsparcie w dbaniu o budynek: katolicy pokrywają część kosztów dekoracji kwietnej, sprzątania czy ogrzewania.

O ile udostępnienie kościoła katolikom wydaje się decyzją pragmatyczną - obecnie katolicy i protestanci dzielą się kosztami utrzymania budynku - to jednak sposób, w jaki o tej decyzji mówił urzędujący pastor, wskazuje też na szerszy kontekst polityczny. Podczas rozmowy fakt wspólnego użytkowania kościoła przedstawił w kontekście debat medialnych na temat chrześcijańskich wartości jako podstawy europejskiej wspólnoty kulturowej. Jego zdaniem, nawet jeśli aktywne uczestnictwo w życiu religijnym ma niewielkie znaczenie w okolicach Löcknitz, to jednak religia chrześcijańska jest spleciona $\mathrm{z}$ wartościami, które uznaje się za europejskie. Pastor nie chciał się wdawać w dyskusję o tym, jakie konkretnie są to wartości - zdawał sobie w pełni sprawę z drażliwości tego tematu. Nie był też przeciwny przyjmowaniu uchodźców z krajów muzułmańskich - wprost przeciwnie, uznawał za obowiązek pomoc osobom z krajów objętych wojną czy kataklizmami. Jednak uznał, że przekazując kościół w użytkowanie - tylko na pewien czas, jak podkreślał, dopóki nie wybudują własnej świątyni - wspólnocie katolickiej, wspiera religię chrześcijańską i zawarte w niej wartości, będące podstawą życia nie tylko religijnego. $\mathrm{W}$ jego wypowiedzi chodziło nie tyle o jego osobiste przekonania, a o to, że to, co jeszcze kilka lat temu wydawało się wielu niemieckim mieszkańcom Löcknitz nieuprawnione, czyli współużytkowanie kościoła z polskimi katolikami ${ }^{16}$, w nowej sytuacji politycznej stało się akceptowalne, a nawet pożądane. Jak powiedział, dla wielu mieszkańców Löcknitz stało się jasne, że z Polakami i katolikami łączą ich chrześcijańskie korzenie i że lepiej ich dopuścić do współużytkowania niż obawiać się, że do wieży kościelnej dobudowane zostaną minarety.

Należy zwrócić uwagę, że tak samo jak w Rosow o losie budynku kościelnego w Löcknitz wypowiadają się nie tylko osoby praktykujące czy nawet zadeklarowane jako członkowie i członkinie danego kościoła, lecz wszyscy mieszkańcy miasta. Ta sytuacja pokazuje nam nie tylko, że budynek kościelny jest ważnym elementem krajobrazu miejscowości i czynnikiem budującym tożsamość jej mieszkańców. Pokazuje także, jak ważne są elementy historycznie związane z obecnością religii w Europie dla procesów, które sytuowane są w sferze świeckiej.

Jednakże w tym wypadku nie możemy mówić o niereligijnym czy postreligijnym wykorzystaniu budynku kościelnego. To, że historycznie tworzona kategoria religii jest uwikłana w politykę i relacje władzy, jest podstawą podejścia Asada. Przypadek Löcknitz może pokazać jedynie, gdzie użyteczność wprowadzonych w tym artykule pojęć się kończy. Nie każde splatanie się świeckiego i religijnego ma aspekt niereligijny. Chyba że sam projekt budowania europejskiej tożsamości na odwołaniach do chrześcijańskich korzeni uznamy za niereligijne wykorzystanie religijnego dziedzictwa.

${ }^{16}$ Rozmowy na ten temat były prowadzone już od kilku lat. Jednak dopiero zmiana na stanowisku pastora doprowadziła do zakończenia negocjacji i rozpoczęcia współużytkowania. 
Gdy czytamy o tym, jak krzyż staje się symbolem politycznym (Zubrzycki 2014) lub jak modlitwa wykorzystywana jest do pozareligijnych celów (Zynek-Mahometa 2018), należy pamiętać, że kierujemy naszą uwagę na religię jako kategorię historyczną, ukształtowaną w procesie zachodzącym w konkretnym miejscu i czasie. Perspektywa postsekularna w rozumieniu Jürgena Habermasa (2001) jest w tym ujęciu także produktem szczególnego historycznego procesu europejskiej sekularyzacji, której częścią było oddzielanie tego, co religijne, od tego, co świeckie, tego, co metafizyczne, od tego, co pragmatyczne, i tego, co duchowe, od tego, co materialne. Nie powinno nas jednak dziwić, że w praktyce etnograficznej elementy religijne, świeckie, polityczne, metafizyczne i pragmatyczne są splecione bądź splatane wciąż na nowo. Pytanie o to, jaką rolę odgrywa religia w przestrzeni publicznej, czy jaką funkcję pełni $\mathrm{w}$ procesach politycznych jest $\mathrm{w}$ gruncie rzeczy pytaniem o wzajemne definiowanie się świeckiego i religijnego - nie tylko o to, gdzie przebiega określana społecznie granica między religijnym a świeckim, ale też czy i po co jest ona w ogóle tworzona?

Pojęcie niereligijności i postreligijności swoją analityczną wartość czerpią z doświadczenia europejskiej nowoczesności. To właśnie idea pożądanej rozdzielności świeckiego i religijnego pozwala na użycie tych terminów do analizy sytuacji przedstawionych w niniejszym artykule. Postreligijność opisuje relację ponadto między tym, czym religia była w określonym miejscu i czasie dla określonych osób, a tym, czym się w ich odbiorze stała.

Birgit Meyer i Mattijs van de Port (2018) piszą, że antropologiczne studia nad dziedzictwem zatrzymują się często tam, gdzie dopiero powinny się zaczynać, skupiając się na pokazaniu, że zachodzi konstrukcja przeszłości w teraźniejszości. Autorzy ci wzywają do zajęcia się tym, jak dziedzictwo staje się realne, jakimi środkami, przez jakie formy zmysłowe czy w jakiej estetyce perswazji następuje jego konstruowanie. Historycznie ukształtowana kategoria religii dostarcza wielu narzędzi pozwalających na konstruowanie rzeczywistości. Aleksander Tölle widział w religijnej architekturze i religijnej organizacji przestrzeni czynnik, który może prowadzić do pozytywnego spojrzenia na partnerów danej interakcji. Jednak elementy religii historycznej istnieją relacyjnie - są one narzędziami, które w konkretnym miejscu i czasie mogą być użyte dla różnorakich celów przez aktorów religijnych i niereligijnych. Postreligijność i niereligijność nie są trwałymi cechami danego miejsca, przedmiotu, działania czy zjawiska. Jako postreligijna i niereligijna może być określana jedynie relacja budowana w konkretnym miejscu i czasie.

\section{LITERATURA}

A s a d Ta la 1 1993, Genealogies of religion: Discipline and reasons of power in Christianity and Islam, Johns Hopkins University Press, Baltimore.

A s a d Tala 1 2003, Formations of the secular: Christianity, Islam, modernity, Stanford University Press, Stanford. 
B a logh Péter 2013, Sleeping abroad but working at home: Cross-border residential mobility between transnationalism and (re)bordering, Geografiska Annaler Series B: Human Geography, vol. 95, nr 2, s. 189-204.

D avie Grace 1994, Religion in Britain since 1945: Believing without belonging, Wiley-Blackwell, Oxford.

Davie Grace 2006, Religion in Europe in the 21 st century: the factors to take into account, European Journal of Sociology/Archives Européennes de Sociologie, vol. 47, nr 2, s. 271-296.

Dohmann Albrecht 1964, Der Wiederaufbau der Kirchen in der Deutschen Demokratischen Republik, Union Verlag, Berlin.

Engelke Matthew 2014, Christianity and the anthropology of secular humanism, Current Anthropology, vol. 55 (S10), s. 292-301.

Engelke Matthew 2015, "Good without God". Happiness and pleasure among the humanists, HAU: Journal of Ethnographic Theory, vol. 5, nr 3, s. 69-91.

Engler Wolfgang, Hensel Jan a 2018, Wer Wir Sind. Die Erfahrung ostdeutsch zu sein, Aufbau Verlag, Berlin.

Frings Thomas, Honkomp Engelbert, Peitz Alois, Lechtape Andreas, Bönte Michael, Richters Christian, Schmitz Gisbert 2007, Gestaltete Umbrüche: Kirchen im Bistum Münster zwischen Neugestaltung und Umnutzung, Dialogverlag, Münster.

Gärtner Christel, Pollack Detlef, Wohlrab-Sahr Monika 2013, Atheismus und religiöse Indifferenz, Springer-Verlag, Wiesbaden.

Green S a rah 2017, Lines, traces and tidemarks: further reflections on forms of borders, [w:] O. Demetriou, R. Dimova (red.), The Political Materialities of Borders: New Theoretical Direction, Manchester University Press, Manchester, s. 67-83.

H a b e r m a s Jürge n 2001, Faith and knowledge: Acceptance speech, Peace Prize of the German Publishers and Booksellers Association, https://www.friedenspreis-des-deutschen-buchhandels. de/sixcms/media.php/1290/2001\%20Acceptance\%20Speech\%20Juergen\%20Habermas.pdf dostęp 11.12.2019.

Hafner Johann, Völkening Helga, Becci Irene 2018, Glaube in Potsdam, Band I: Religiöse, spirituelle und weltanschauliche Gemeinschaften: Beschreibungen und Analysen, Ergon, Baden Baden.

Ha le m b a A n i es zka 2017, Tworzenie pogranicza a życie przy granicy. Refleksje terminologiczne w świetle badań przy granicy polsko-niemieckiej, Etnografia Polska, vol. 61, nr 1-2, s. 5-20.

$\mathrm{H}$ a y d e n R o b e r t 2002, Antagonistic tolerance: Competitive sharing of religious sites in South Asia and the Balkans, Current Anthropology, vol. 43, nr 2, s. 205-231.

$\mathrm{Höh} \mathrm{n} \mathrm{Hans-J} \mathrm{o} \mathrm{a} \mathrm{ch} \mathrm{i} \mathrm{m} \mathrm{2006,} \mathrm{Renaissance} \mathrm{of} \mathrm{religion.} \mathrm{Clarifications} \mathrm{on} \mathrm{a} \mathrm{disputed} \mathrm{topic,} \mathrm{Herder}$ Korrespondenz, vol. 12, s. 605-608.

Le e L o is 2012, Locating nonreligion, in mind, body and space: New research methods for a new field, Annual Review of the Sociology of Religion, vol. 3, s. 135-157.

L u bańska Magda le n a 2017, Pogranicze jako przestrzeń strategicznej koegzystencji grup mieszanych religijnie, Etnografia Polska, vol. 61, nr 1-2, s. 21-41.

Meyer Birgit, van de Port Matijs 2018, Sense and essence. Heritage and the cultural construction of the real, Berghahn, Oxford, New York.

Meys Oliver, Gropp Birgit 2010, Kirchen im Wandel: veränderte Nutzung von denkmalgeschützten Kirchen, GWN, Neuss.

Kiley Christopher J. 2004, Convert! The adaptive reuse of churches, Thesis, MIT, Dept. of Urban Studies and Planning.

Köp ping Paula 2018, Integriert doch erst mal uns!: Eine Streitschrift für den Osten, Ch. Links Verlag, Berlin.

Lau Burkhard, Lau Karl, Korzec Cezary, Scheller Karsten, Seeliger Dietrich 2018, 775 Jahre Rosow. Festschrift zum 775 Jubiläum, Ortsbeirat Rosow, Gemeinde Mescherin. 
Peperkamp Esther, Rajtar Małgorzata (red.) 2010, Religion and the secular in Eastern Germany, 1945 to the present, Brill, Leiden-Boston.

Poll a ck Det lef 2002, The change in religion and church in Eastern Germany after 1989: A research note, Sociology of Religion, vol. 63, nr 3, s. 373-387.

Poll a ck Detlef, P i ckel Gert 2000, Religiöser und kirchlicher Wandel in Ostdeutschland 19891999, Bd. 3, Springer-Verlag, Opladen.

Quack Johannes 2014, Outline of a relational approach to "Nonreligion", Method \& Theory in the Study of Religion, vol. 26, nr 4-5, s. 439-469.

Rög e r Mar e n 2016, Ucieczka, wypędzenie i przesiedlenie. Medialne wspomnienia i debaty w Niemczech $i$ w Polsce po 1989 roku, Wydawnictwo Nauka i Innowacje, Poznań.

Rutk ow ska B og n a 2019, Zamieszkując „Pogranicze”. Migracja przygraniczna z Polski do Niemiec w doświadczeniach dzieci i rodziców, Etnografia Polska, vol. 63, z. 1-2, s. 23-41.

S a dło ń Wo j c i e ch 2019, Annuarium Statisticum Ecclesiae in Polonia, Instytut Statystyki Kościoła Katolickiego, Warszawa.

Strathern Marilyn 2018, Relations, Cambridge Encyclopedia of Anthropology, https://www. anthroencyclopedia.com/entry/relations, dostęp 11.12.2019.

Tölle A leks ander 2013, Ku transgraniczności przestrzeni religijnej. Projekty na polsko-niemieckim obszarze przygranicznym, Peregrinus Cracoviensis, vol. 24, nr 4, s. 117-135.

Tölle Aleksander 2016, From ruins to places of reconciliation, togetherness, community and ecumenism. Restored city churches in the German-Polish borderland, [w:] M. Kowalewski, A.M. Królikowska (red.), Transforming urban sacred places in Poland and Germany, Nomos Verlagsgesellschaft, s. 137-152.

Will e b r a n d M a r t in 2013, 'Respekt vor dem Raum' statt 'Verzweckung der Kirche'. Die Umgestaltung einer Kirche schließt an deren architektonische Kommunikation an, Communicatio Socialis, vol. 46, nr 2, s. 241-246.

Wohlrab-Sahr Monika, B u r chardt Marian 2017, Revisiting the Secular: Multiple Secularities and Pathways to Modernity, Kolleg-Forschergruppe Multiple Secularities, Leipzig.

Wohlrab-Sahr Monika, Kaden Tom 2014, Exploring the Non-Religious. Societal Norms, Attitudes and Identities, Arenas of Conflict, Archives de sciences sociales des religions, vol. 167, s. $105-125$.

Wohlrab-S ahr Monika 2011, Forced secularity? On the appropriation of repressive secularization, Religion and Society in Central and Eastern Europe, vol. 4, $\mathrm{nr}$ 1, s. 63-77.

Wohlrab-Sahr Monika, Karstein Uta, Schmidt-Lux Thomas 2009, Forcierte Säkularität: religiöser Wandel und Generationendynamik im Osten Deutschlands, Campus Verlag, Frankfurt am Main.

Z ab or ski Marcin 2007, Przeszłość w teraźniejszości. Niemieccy wypędzeni w polskich mediach, Przegląd Zachodni, vol. 319, nr 01, s. 199-215.

Zubrzycki G en evi ève 2014, Krzyże w Auschwitz: tożsamość narodowa, nacjonalizm i religia w postkomunistycznej Polsce, Zakład Wydawniczy Nomos, Kraków.

$\mathrm{Zuckerman} \mathrm{Phil} \mathrm{2008,} \mathrm{Society} \mathrm{without} \mathrm{God:} \mathrm{What} \mathrm{the} \mathrm{least} \mathrm{religious} \mathrm{nations} \mathrm{can} \mathrm{tell} \mathrm{us} \mathrm{about}$ contentment, NYU Press, New York.

Zynek-Mahometa Just yn a 2018, „Droga do wolności” czy „teatr hipokryzji”? O „Różańcu Do Granic” w dyskursie internetowym portalu społecznościowego Facebook, Lud. Organ Polskiego Towarzystwa Ludoznawczego i Komitetu Nauk Etnologicznych PAN, vol. 102, s. 383-407. 
AGNIESZKA HALEMBA

\section{POSTRELIGIOUS AND NONRELIGIOUS USE OF CHURCH BUILDINGS IN THE POLISH-GERMAN BORDERLAND}

Keywords: Nonreligion, postreligion, Talal Asad, church buildings, Polish-German relations

In the northern part of the former GDR there are many church buildings that are renovated, well taken care of but serving small number of believers. Although retaining some religious functions, they are at the same time used by actors that define themselves as not religious. Using concepts of nonreligous and postreligious as analytical terms referring to specific kinds of relations between religious and secular fields, I analyze cases of three Protestant churches, within the context of Polish-German relations in this region. I show that we should bring to a logical conclusion Talal Asad's observation that religion is a historical category which is constantly redefined through its relationship with an equally mutable category of the secular.

A.H.

Adres Autorki:

prof. IAE PAN dr hab. Agnieszka Halemba

Instytut Archeologii i Etnologii, PAN

Al. Solidarności 105, 00-140 Warszawa

E-mail: a.halemba@uw.edu.pl

ORCID: https://orcid.org/0000-0002-3900-4880 